\title{
FILM AS A COMPLEMENT TO THE WRITTEN TEXT: REFLECTIONS ON USING THE STERILIZATION OF LEILANI MUIR TO TEACH MUIR V. ALBERTA
}

\author{
ELIZABETH ADJIN-TETTEY AND FREYA KODAR*
}

In this article the authors look at their experiences teaching the trespass torts to law students using a documentary film about Muir v. Alberta. The case was brought by Leilani Muir against the government of Alberta for battery and false imprisonment and for sterilizing her without her knowledge or consent. The documentary follows Muir's court case, and interweaves her personal story with the larger social history of the eugenics movement and the development of The Sexual Sterilization Act. The authors begin with a description of the Muir documentary and a discussion of the ways in which the texts, written and filmic, work together in the context of telling Muir's story. The authors then discuss film as a medium for telling legal stories. Finally, the authors reflect on their classroom experiences with the various Muir texts, and the ways in which the film assists them in teaching both the particular case and torts more generally. The authors suggest that complementing case reports with documentaries about them, or events related to the case, helps to provide alternative and sometimes counter stories to the official account.
Les auteurs de cet article examinent leurs expériences d'enseignement des délits d'atteintes à des étudiants en droit en utilisant un documentaire sur Muir c. Alberta. Leilani Muir lança une poursuite contre le gouvernement de l'Alberta pour batterie, séquestration et stérilisation sans sa connaissance ou consentement. Le documentaire suit la cause de Muir et entrelace sa vie personnelle avec la grande histoire sociale du mouvement eugénique et le développement de la loi sur la stérilisation sexuelle (The Sexual Sterilization Act). Les auteurs commencent par donner une description du documentaire et une discussion des manières dont les textes écrits et les films fonctionnent ensemble dans le contexte pour raconter l'histoire de Muir. Les auteurs discutent ensuite le film comme moyen de raconter des histoires juridiques. Enfin, les auteurs réfléchissent à leurs expériences en classe avec les divers textes sur Muir et les manières dont le film les aide à enseigner à la fois la cause spécifique et les atteintes au sens général. Les auteurs suggèrent que le fait d'ajouter des rapports sur les rapports sur les causes avec des documentaires ou des événements pertinents aide à donner une alternative et parfois des versions contraires à la version officielle.

\section{TABLE OF CONTENTS}

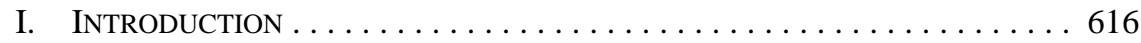

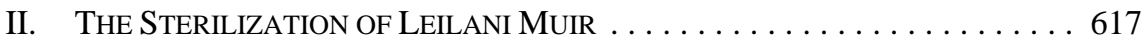

A. The WRITtEN TEXT . . . . . . . . . . . . . . . . . . . . . . . 617

B. The DOCUMENTARY TEXT ................. 618

C. Considering the TeXts Together $\ldots \ldots \ldots \ldots \ldots \ldots 19$

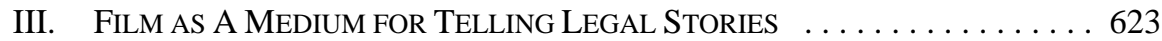

IV. OUR CLASSROOM EXPERIENCE WITH THE

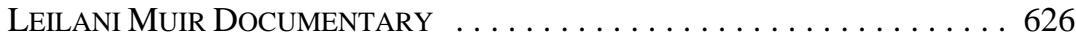

V. CONCLUSION . . . . . . . . . . . . . . . . . . . . . . . . . 629

Faculty of Law, University of Victoria. We would like to thank Scott Bergen, Lyndsey Delamont, Margo Foster, and Rose Keates for research assistance and, in Margo's case, transcript creation; Serena Ableson with the Faculty's Law Library for her assistance and navigation of the Copyright Act to preserve a copy of the Muir documentary; participants at the Canadian Association of Law Teachers Conference, Ottawa, May 2009, who provided feedback on our presentation of the work; and Rebecca Johnson and anonymous reviewers for their comments. This article has its origins in a short piece that was part of a collection of stories about using film in the law school classroom: "Using Film in the Classroom: The Call and the Responses” (2009) 21 C.J.W.L. 197 (Special Issue: Law, Film and Feminism, Gillian Calder \& Rebecca Johnson, eds.). 


\section{INTRODUCTION}

In teaching and learning law it is easy to lose sight of the fact that legal cases are about real people, problems, and tragedies. This is partly because the process of legal reasoning in the common law tradition often necessitates abstracting individuals at the centre of the action and viewing them as legal subjects rather than persons whose interests have been harmed by others. ${ }^{1}$ Like many other law professors, one strategy we give students in our torts classes is to read cases as stories; to think about who is in the story, what happened, what the court is trying to decide, and why it matters to "the law."2 Not only does this strategy help students relate to the cases they read and place them in their historical and social contexts, but it also increases their understanding, level of engagement, and appreciation of the legal principles arising from the case. ${ }^{3}$

From a critical pedagogy perspective, setting up cases as stories and legal reasoning as a form of storytelling can open up space for discussion and reflection on factors that influence legal narratives such as social location and perspective. ${ }^{4}$ We can explore questions about which facts and perspectives are "relevant" or included, and which are absent or "irrelevant" to the legal story the court writes. As Diana Majury has noted, "claimants tend to disappear from the case as it progresses through the appeal process. Their experiences are characterized as legal issues to be debated and fought over, while they themselves are often rendered invisible." ${ }^{5}$ This is particularly the case with appellate decisions that tend to be the staple of the law school curriculum. These cases are often not about the actual parties or their stories, but about establishing legal principles based on written records and lawyers' arguments. Approaching cases as stories allows, and perhaps even requires us to, whenever possible, provide additional materials or texts to tell a counter and/or fuller story about a case and the individual(s) involved beyond what appears in the case report, and to highlight the variety of perspectives on a particular event. ${ }^{6}$

This article looks at our experiences using a documentary film about Muir v. Alberta, ${ }^{7}$ one of the cases we use in teaching the trespass torts. The case was brought by Leilani Muir against the Government of Alberta for battery and false imprisonment for confining her to

Abstraction is a central feature of legal liberalism and the dominant form of legal reasoning or jurisprudential discourse in the common law tradition. For a critique of abstraction, how it ignores counter-assumptions, and its effect on marginalized subjects such as women, see Mari J. Matsuda, “Liberal Jurisprudence and Abstracted Visions of Human Nature: A Feminist Critique of Rawls' Theory of Justice” (1986) 16 N.M.L. Rev. 613.

See Larry Catá Backer, “Tweaking Facts, Speaking Judgment: Judicial Transmogrification of Case Narrative as Jurisprudence in the United States and Britain” (1998) 6 S. Cal. Interdisciplinary L.J. 611; Binny Miller, “Teaching Case Theory” (2002) 9 Clinical L. Rev. 293 at 302.

3 For discussions of teaching cases as stories, see Elizabeth J. Samuels, "Stories Out of School: Teaching the Case of Brown v. Voss” (1995) 16 Cardozo L. Rev. 1445 at 1446-49, 1501-506; Thomas Ross, “Teaching Constitutional Law Stories” (2005) 55 J. Legal Educ. 126 at 127-28.

4 See Richard K. Sherwin, "Law Frames: Historical Truth and Narrative Necessity in a Criminal Case" (1994) 47 Stan. L. Rev. 39 at 40-41.

5 Diana Majury, "Introducing the Women’s Court of Canada” (2006) 18 C.J.W.L. 1 at 10. See also Ross, supra note 3 at $128-29$.

$6 \quad$ See Richard Delgado \& Jean Stefancic, Critical Race Theory: An Introduction (New York: New York University Press, 2001) c. 3; Richard Delgado, The Rodrigo Chronicles: Conversations about America and Race (New York: New York University Press, 1995); Derrick Bell, And We Are Not Saved: The Elusive Quest for Racial Justice (New York: Basic Books, 1987); Mary Whisner, "Story Time in the Law Library” (2004) 96 Law Libr. J. 371 at 374-76; Miller, supra note 2 at 304. (1996), 179 A.R. 321 (Q.B.) [Muir]. 
the Provincial Training School for Mental Defectives (PTS) in Red Deer ${ }^{8}$ when she was ten years old, and for sterilizing her without her knowledge or consent at the age of 14. The Sterilization of Leilani Muir ${ }^{9}$ follows Muir's court case, and interweaves her personal story with the larger social history of the eugenics movement and the development of The Sexual Sterilization Act. ${ }^{10}$ We begin with a description of the Muir documentary and a discussion of the ways in which the texts, written and filmic, work together in the context of telling Muir's story. This is followed by a discussion of film, and documentary film in particular, as a medium for telling legal stories. In the final section, we reflect on our classroom experiences with the various Muir texts and the ways in which the film assists us in teaching both the particular case and torts more generally.

\section{The Sterillzation OF LEILANi MUIR}

\section{A. The Written TeXt}

Muir sued the Alberta government for both battery and false imprisonment. The province admitted its liability in battery for the sterilization because the provincial Eugenics Board (Board) acted outside the scope of the Sexual Sterilization Act when it ordered her sterilization. The Act provided that sterilization was only to be considered when a person was about to be discharged and it was necessary to eliminate the risk of procreation. ${ }^{11}$ Muir was never discharged nor considered for discharge since she left PTS on her own accord and against the advice of the school. ${ }^{12}$ The case proceeded to trial on the false imprisonment claim and the issue of the quantum of damages for each claim. In admitting liability for the battery, the province chose not to invoke the limitations defence that would have been a complete bar to Muir's claim. Muir had two years from the time she became an adult or discovered her wrongful sterilization to initiate her claim. ${ }^{13}$ Although she became aware of her sterilization during her first marriage, she did not bring the lawsuit until many years later, by which time her claim was deemed time-barred.

Even as a written text, Muir provides a fuller "story" of the case than is usual, since it includes as an appendix Professor Gerald Robertson's expert witness report on the history of the Alberta sterilization legislation ${ }^{14}$ and the influence of the eugenics movement on its

Subsequently renamed the Michener Centre.

VHS (Montreal: National Film Board of Canada, 1996) [Sterilization of Leilani Muir].

R.S.A. 1942, c. 194 [Sexual Sterilization Act]. The legislation was introduced in the Alberta Legislature in 1927 and ultimately enacted in 1928: The Sexual Sterilization Act, S.A. 1928, c. 37. The original version of the Act permitted sterilization only with the consent of the subject, if competent, or a designated substitute - a parent, spouse, guardian, or the Minister of Health (s. 6). A 1937 amendment to the Act removed the consent requirement except where the person was psychotic: An Act to Amend The Sexual Sterilization Act, S.A. 1937, c. 47, ss. 5-6. The Sexual Sterilization Act was further amended in 1942 to expand the categories of persons who could be sterilized (ss. 6-8). The legislation was repealed in 1972: The Sexual Sterilization Repeal Act, 1972, S.A. 1972, c. 87 [Repeal Act]. See "Eugenics: Keeping Canada Sane" The Canadian Encyclopedia, online: The Canadian Encyclopedia <http:// thecanadianencyclopedia.com/index.cfm?PgNm=ArchivedFeatures\&Params=A2126>; "Sexual Sterilization Act of Alberta" Wikipedia, online: Wikipedia <http://en.wikipedia.org/wiki/Sexual_ Sterilization_Act_of_Alberta>; Lee Craig, “A dark chapter of history reexamined” Folio Focus (27 May 2007), online: University of Alberta, Faculty of Education, Educational Pyschology <http://www. uofaweb.ualberta.ca/edpsychology/news.cfm?story=60382>.

Sexual Sterilization Act, ibid., ss. 4(1), 6.

Muir, supra note 7 at para. 4.

Limitation of Actions Act, R.S.A. 1980, c. L-15, ss. 51(b), 52, 57-58.

Muir, supra note 7, App. A: "Report of Expert Witness." 
development and implementation. ${ }^{15}$ Robertson's report gives readers a broader context for understanding the victimization of Muir and others sterilized under the Sexual Sterilization Act. Despite the "fuller" story provided by the expert witness report and the testimony of other experts referenced in Veit J.'s decision, students are still reading about the case and "hearing” Muir's testimony through these lenses of privilege and expertise. ${ }^{16}$ They are not given an opportunity to see and hear her personal account, or those of others who were confined and sterilized under the legislation. The Sterilization of Leilani Muir goes some way to providing this. ${ }^{17}$

\section{B. THE DOCUMENTARY TEXT}

The documentary combines narratives with the storytelling of the involved parties: victims, their lawyers, persons who served on the Eugenics Board, and experts who provide context for the eugenics movement and the history of the Sexual Sterilization Act. Broadly speaking, it asserts two interrelated stories: one about Muir's experience and the litigation process, and the other about the eugenics movement and its history in Alberta. The story presented in the documentary shows the experiences, suffering, and feelings of Muir and of others who were institutionalized and sterilized. The viewer is generally not presented with a view of either the government's side of the story or the litigation process. The film also asserts a link between the policy of eugenics underpinning Alberta's sterilization legislation and the institutionalization and sterilization programs undertaken by Nazi Germany some five years later. The filmmaker uses this link as a vehicle to denounce the discriminatory focus of the Nazi regime in Germany and eugenics philosophy in general. ${ }^{18}$

The documentary is a hybrid of the expositional and observational genres; ${ }^{19}$ it uses still images from photographs of the historical events, Muir's childhood, life at the PTS, the operation of the Eugenics Board, etc., accompanied by narrations of what the images represent. Throughout the film, a male narrative voice-over ties the footage together, providing background information about the people and events being shown as well as the eugenics movement. At times, other voices dramatize testimony and speeches, while still

15 It is unusual to find a complete expert witness report as part of a court decision. Decisions often reference or quote expert testimony or reports, and expert witness reports and transcripts of their testimony are available to the public if they go through the trouble of accessing the court file.

16 Additional information about a case may be obtained from the parties' factums and expert reports, where applicable. These may give a bigger picture of the case than what appears in the case report. However, these sources are also constructed to tell particular stories, and in any event privilege the written text as authoritative.

17 There were also several news stories about Muir's case. They tended to focus on the fact that it was the first such case to be successful and on the quantum of the damage award. Like all news stories, they often reflected the author/media outlet's perspective on the case: see e.g. Janice Tibbetts, "Woman gets $\$ 973,000$ cheque in wrongful-sterilization case” The Vancouver Sun (1 March 1996) A5; “Alberta pays sterilized woman a million” The Toronto Star (2 March 1996) A9; Larry Johnsrude, “Alberta won’t apologize for sterilization of woman” The [Montreal] Gazette (13 March 1996) A12.

Sterilization of Leilani Muir, supra note 9 at 0:26-0:28.

Film scholars have struggled with defining the documentary and its place on the continuum between fiction and non-fiction film. Some have categorized documentaries as either indexical record, moving images of the pro-filmic event, or as assertion where the filmmaker "make[s] assertions about the actual world”: Carl Plantinga, "What a Documentary Is, After All” (2005) 63 The Journal of Aesthetics and Art Criticism 105 at 107. Plantinga provides an overview and critique of these categories (at 105-11). Film theorist Bill Nichols has developed an alternative taxonomy of documentaries that divides them into "six documentary modes ... the poetic, expository, observational, participatory, reflexive, and performative": Plantinga at 109, describing the taxonomy discussed in Bill Nichols, Introduction to Documentary (Bloomington: Indiana University Press, 2001). We draw on both taxonomies in our discussion. 
others read from historical documents, including some of the evidence that was entered at the trial.

It also uses the interactive mode of representation where Muir is given an opportunity to express her feelings about her treatment and the outcome of the case in a press conference as she answers questions from reporters. In this regard, the documentary is partly a reconstruction of historical events, and reactions to those events both in their historical contexts and their continuing effects on the subject. Hence, truth claims otherwise accorded to documentaries may be contested in relation to the representations in the documentary, such as the ability of the subjects to accurately and objectively recount historical events that have substantially affected them..$^{20}$

The documentary is also observational because it chronicles the unfolding of some real life events. Meetings between Muir and her lawyers are shown, as are some of their press conferences. Viewers also hear directly from a former member of the Board, who also testified at the trial, and others who speak about the history of the eugenics movement and the legislative scheme. Muir and her lawyers speak to viewers about the court process and Muir's reasons for pursuing the case. The documentary is structured in such a way as to invite viewers to judge the story by making it appear that the subjects are directly speaking to viewers and appealing to their conscience to pass judgment on their treatment by the province.

\section{CONSIDERING THE TEXTS TOGETHER}

Like many case reports, the Muir judgment is an account of her story told by others and centres on the legal issues raised rather than a personal narrative. The report contains a short account of Muir's evidence and relays doubts about her credibility as a witness in relation to certain matters. ${ }^{21}$ It includes evidence from expert witnesses, school records, and communications among professionals, school officials, and her parents. Although it was likely part of her evidence, the public record does not adequately reflect Muir's personal story. The decision provides information about Muir's home environment and her relationship with her parents as part of the factual chronology of her admittance to the PTS and subsequent confinement and sterilization. In places, the Court touches on her home situation, finding that she "had a very bad relationship with her mother"; 22 that she was "denied food when she was with her family",23 referring to her mother as a "parent who can no longer manage their child"; ${ }^{24}$ and quoting from a 1964 assessment of the parental home in which a social worker stated that "Mrs. Scorah [Muir's mother] was very definite that she didn’t want [Leilani]. She emphasized the financial reasons but I feel she has little affection for [Leilani] and just can't face a future in which the supervision of [Leilani] would be permanent." 25

For instance, Veit J. expresses her doubt about Muir's credibility in relation to some aspects of her testimony that were uncorroborated, among other things, because she found her recollection of some events to be questionable: Muir, supra note 7 at paras. 66-69.

Ibid. at paras. 65-76.

Ibid. at para. 70 .

Ibid.

Ibid. at para. 159.

Ibid. at para. 40. 
In the documentary, Muir tells viewers about the childhood neglect and her mother's abuse, including the fact that her mother made it clear to her that she did not want to have girls. ${ }^{26}$ Muir's explanation of her mother's attitude towards her and her tendency to steal food as culminating in the decision to send her to the PTS, where she was wrongfully confined, emotionally and physically abused, and wrongfully sterilized, creates a much more visceral impact for the viewer than the written decision.

The complementarity between written text/judgment and filmic text cuts both ways. In the documentary, there are some gaps in Muir's story and places where the case report provides a fuller account because of the human tendency to self-censor unfavourable aspects in one's account of events. For instance, in the documentary Muir simply states that she was devastated when her attempt to adopt a child was unsuccessful and that it affected the stability of her marriage, but does not state the reason why the adoption fell through. The case report provides more information about this. ${ }^{27}$

In terms of the litigation process itself, Muir's reasons for pursuing the case as she articulates them in the documentary provide insight into the many reasons people choose to pursue justice through litigation, and some of the benefits of proceeding with a court case, rather than, for instance, seeking an out-of-court settlement. Muir states that she wants a public apology and for the public to know what happened to her and others institutionalized and sterilized under the legislation. ${ }^{28}$ The importance of having a public court proceeding and decision is highlighted in her discussion of what accepting a settlement would mean to her: "If I'd settled, they would've said that was hush money, and people would not have known to this date what really happened in Canada, what should never have happened." ${ }^{29}$ As David King notes, Muir's case was a symbol for all those who had been treated in a similar manner. $^{30}$

If her success is judged based on how much compensation she recovered, then one likely draws a different conclusion from the case report than from viewing the documentary. In footage of the press conference after the Court's decision, Muir emphasizes the inadequacy of monetary damages for her victimization. She states: "No amount of money could ever make up for what I went through and what I will go through until the day I die." ${ }^{\text {"1 }}$ Yet, she notes her satisfaction with the process, the public recognition of the wrong done to her, and the fact that her case creates a precedent for other survivors and an awareness of this dark chapter in the province's history. She discusses the ways in which the process and the

Sterilization of Leilani Muir, supra note 9 at 0:21.

Muir, supra note 7 at para. 49; ibid. at 0:36.

Sterilization of Leilani Muir, ibid. at 0:22.

Ibid. at 0:23. For a discussion of the therapeutic importance of a litigation option for survivors of historical and institutional abuse, see Elizabeth Adjin-Tettey, "Righting Past Wrongs Through Contextualization: Assessing Claims of Aboriginal Survivors of Historical and Institutional Abuses" (2007) 25 Windsor Y.B. Access Just. 95 at $111 \mathrm{ff.}$

Sterilization of Leilani Muir, ibid. at 0:42. King was the Alberta MLA who introduced the Bill leading to the enactment of the Repeal Act, supra note 10: see Muir, supra note 7, App. A: "Report of Expert Witness” at 361.

Sterilization of Leilani Muir, ibid. at 0:44. In fact, in an interview following her court “victory,” Muir makes it clear that the compensation she received will not make her rich, that she will not have much money left after paying her legal fees and other expenses, and that she still needs to work to look after her needs: Janelle Holden, “The Final Countdown” 25:48 Alberta Report (16 November 1998) 10. 
decision have made her more self-confident and less self-blaming. ${ }^{32}$ Thus, the documentary highlights how a particular plaintiff experienced the litigation process and its outcome and the therapeutic benefits that the process provides for victims of historical abuse, especially those victimized by powerful entities, all of which is often absent from the case record.

The decision, and more particularly Robertson's expert report, situates Muir's confinement and sterilization within the broader eugenics context of the early twentieth century. Eugenicists believed that the human race could be improved through the procreation of individuals with socially desirable characteristics, which were believed to be hereditary. The corollary to this belief was the assumption that socially undesirable characteristics such as criminality, poverty, mental illness, and mental retardation were also inherited and their incidence in the human population could be controlled through discouraging the procreation of individuals with these "unfavourable" characteristics. Proponents of these ideas pursued a number of legal avenues to discourage procreation by individuals with such characteristics, including sterilization, segregation, institutionalization, and marriage prohibition. ${ }^{33}$ As Robertson discusses, proponents of eugenics were not only concerned with "improving" the human gene pool, they were also driven by concerns about public order and public health. More particularly, there existed a widely held belief, based on media reports and academic and "scientific" literature, of a link between "deficiency" and criminality, and of the prevalence of criminality among immigrants, meaning that the sterilization legislation was "[i]n essence ... a social control measure, aimed at preventing (or at least reducing) criminal and morally delinquent behaviour in Alberta." ${ }^{34}$

While the written texts we assign to our students provide this important social and historical context, much of it is "separated" from the central "legal" questions the Court grapples with because it is placed in the Appendix. ${ }^{35}$ The documentary recentres the social and historical context, presenting it through interviews with academics, and through voiceover narratives accompanied by images that reinforce the audio, such as photos and footage of the movement's founder, of people being measured, of poor children, of members of political organizations who lobbied for the legislation, such as the United Farm Women's Association, and of immigrants. Actors also dramatize statements and speeches in support of sterilization by public figures such as Emily Murphy. ${ }^{36}$ Both the Robertson report and the documentary show that poor people, women, First Nations and Métis, immigrants, people

Sterilization of Leilani Muir, ibid. at 0:34-0:35, 0:44-0:45;“'Sterile victim runs for NDs: Bill 11 sparked woman's decision to enter race” Calgary Herald (17 February 2001) A11.

33 Muir, supra note 7, App. A: "Report of Expert Witness," "The Philosophy of the Eugenics Movement" at 364 and "Criminality" generally.

Ibid., App. A: "Report of Expert Witness," "Conclusion” at 370.

However, the fact that the expert witness report is part of the decision does mean that the information is more "public" than it would have been if the report had been relegated to the court file.

Emily Murphy was the first woman magistrate to be appointed in the British Empire and one of the five women who fought for the recognition of women as legal persons in Canada. For a synopsis of Murphy's life and her achievements, see Kate Nelligan, Historica Minutes: Women: Emily Murphy, online: History by the Minute <http://www.histori.ca/minutes/minute.do?id=10205>. Other social reformers and advocates of women's equality such as Nellie McClung, another of the "Famous Five," also supported the Sexual Sterilization Act and the underlying eugenics philosophy: see Jana Grekul, Harvey Krahn \& Dave Odynak, "Sterilizing the 'Feeble-minded': Eugenics in Alberta, Canada, 19291972" (2004) 17 Journal of Historical Sociology 358 at 378; Jennifer Koshan \& Elizabeth Whitsitt, "The Province of Persons: The Alberta Supreme Court and Women's Equality" in Jonathan Swainger, ed., The Alberta Supreme Court at 100: History \& Authority (Edmonton: University of Alberta Press \& Osgoode Society for Canadian Legal History, 2007) 297 at 302. 
of eastern European heritage, and people living in government institutions were much more likely to have the legislation applied to them than were those people who had social power. ${ }^{37}$ The film also brings out the "scientific" patina, and the twisted logic underpinning eugenics in a way that the written texts do not, as those interviewed debunk the science. As King states: "There was a widespread feeling in North America, the western world, that everything could be remedied with science.... And I think ... there was a widespread feeling that, somewhere at bottom, science and morality were the same thing."38

As well, the documentary gives a more complete picture of how others were affected by the sterilization legislation. Although the case report acknowledges that the plaintiff was not the only person sterilized under the Sexual Sterilization Act, given the individualistic and private nature of litigation there is little attempt to put a face on the other victims of the legislation or highlight the symbolic nature of the action. The decision was also of limited precedential value given the narrow basis on which the case proceeded. ${ }^{39}$ The documentary not only shows the enormity of the problem, but it also features other survivors who speak directly to viewers about their experiences, thereby making real the otherwise faceless victims of wrongful sterilization.

In addition, though the Court found that the Board, which did not receive any information before meetings, dealt with many cases in ten minutes or less, ${ }^{40}$ the documentary sheds further light on the hearing process by contrasting the experiences relayed by a former Board member with those of victims who came before the Board. While the Board member comments that they saw the patients in order to test their intelligence and decide whether they could function in society, ${ }^{41}$ the victims speak of not being aware of who the Board was, of being asked few questions, and of meeting with the Board for approximately five minutes. ${ }^{42}$ Following the hearings, they were taken for surgery and told they were having their appendixes removed or simply that they were going for surgery, but not that they were being sterilized. ${ }^{43}$

Also telling are the divergent attitudes towards sterilization portrayed in the judgment and in the documentary. The judgment grounds the wrongs done to Muir in part on the Board's failure to follow proper procedure in authorizing her sterilization as set out in the legislation, and not on forced sterilization as an inherent affront to bodily integrity, human dignity, and reproductive autonomy. In fact, Veit J. notes that sterilization, whether forced or consensual, may affect people differently. For some it may be neutral, and for others it may only be of mild concern. ${ }^{44}$ This is different from the perception of sterilization portrayed in the documentary. The documentary denounces forced sterilization per se, regardless of how it

Muir, supra note 7 at para. 96; Sterilization of Leilani Muir, supra note 9 at 0:30; Grekul, Krahn \& Odynak, ibid. at 364-65, 371-75; Koshan \& Whitsitt, ibid. Sterilization of Leilani Muir, ibid. at 0:17-0:18.

In fact, Veit J. notes that the Government of Alberta's admission of liability in Muir was not to be perceived as an admission of liability in respect of others who may have been sterilized under the legislation. Rather, it was only liable because the requirements of the Act were not followed before she was irreversibly sterilized: Muir, supra note 7 at para. 128.

Ibid. at para. 95.

Sterilization of Leilani Muir, supra note 9 at 0:31-0:32.

Ibid. at 0:32-0:33.

Ibid. at 0:33-0:34.

Muir, supra note 7 at para. 129. 
actually affects the person. ${ }^{45}$ This portrayal is consistent with trespass tort principles, which are premised on the plaintiff's right to exclusive control over her or his body and to an award of damages for the violation of that right whether it results in tangible injury or not. ${ }^{46}$ Using the film and judgment together gives students a more complete picture of the events that took place and underscores the complementarity of the different texts in telling particular stories.

\section{FILM AS A MEDIUM FOR TELLING LEgAL STORIES}

The increasing use of film, fictional and documentary, to tell stories about law is partly influenced by the perception that moving images and sound recordings of real life events offer the audience entry points into the lives of those involved in the case, along with a picture of the broader contexts that may be omitted in case reports. In this regard films, particularly documentaries, take viewers beyond the "official" accounts in the case reports and allow them to experience the "reality" of the cases. ${ }^{47}$ Visual images, as well as sound recordings of events, provide audiences a rare opportunity to reflect on and interpret images and sounds, and form their own impression and understanding of events. The opportunity to observe body language, facial expression, and demeanour, as well as any subtext that might not be immediately apparent in a written record, produces an affective and embodied response not always possible from engagement with written texts. It allows the viewer a better sense of the meaning of the case to those involved.

In addition, seeing the parties in a case and hearing their perspectives can provide counternarratives to the "official” story. Counter-narratives have the potential to promote social change by challenging dominant stories or perceptions about marginalized people and may be important in transforming the legal system in ways that reflect the voices of hitherto excluded or outsider groups. ${ }^{48}$ As well, viewers may experience the event differently, often based on their own subjective position and identification with or dissociation from those in the story, thereby leading to different constructions of the "truth" or "reality" for the audience. Thus, the use of film challenges the positivist and conventional forms of epistemology in law schools, namely, the hegemony of written texts as represented in case

45 For a discussion of different meanings and responses to non-therapeutic sterilization and the law's role in constructions of bodies, sex, gender, and sexuality, see Kristin Savell, "Sex and the Sacred: Sterilization and Bodily Integrity in English and Canadian Law” (2004) 49 McGill L.J. 1093.

46 See Non-Marine Underwriters, Lloyd's of London v. Scalera, 2000 SCC 24, [2000] 1 S.C.R. 551 at para 16 [Scalera]. See also E. (Mrs.) v. Eve, [1986] 2 S.C.R. 388, regarding the resistance to the sterilization of mentally disabled persons for non-therapeutic purposes regardless of the potential burden of pregnancy and parenthood on their caregivers.

$47 \quad$ See Jessica Silbey, “A History of Representations of Justice: Coincident Preoccupations of Law and Film” in Antoine Masson \& Kevin O’Connor, eds., Representations of Justice (Brussels: P.I.E. Peter Lang, 2007) 131 at 132, for a discussion of this understanding of the relationship between film and the event being filmed.

48 See Judith G. Greenberg \& Robert V. Ward, “Teaching Race and the Law through Narrative” (1995) 30 Wake Forest L. Rev. 323 at 340-45. Advocates of counter-narratives recognize the limited potential of these stories to challenge the status quo, among other things, because they tend to go against the official story that enjoys the status of "truth": see Richard Delgado, "Storytelling for Oppositionists and Others: A Plea for Narrative” (1989) 87 Mich. L. Rev. 2411; Richard Delgado, “The Imperial Scholar” Revisited: How to Marginalize Outsider Writing, Ten Years Later” in Richard Delgado \& Jean Stefancic, eds., Critical Race Theory: The Cutting Edge, 2d ed. (Philadelphia: Temple University Press, 2000) 479 at 485; Richard Delgado \& Jean Stefancic, "Images of the Outsider in American Law and Culture: Can Free Expression Remedy Systemic Social Ills?” in Richard Delgado \& Jean Stefancic, eds., Critical Race Theory: The Cutting Edge, 2d ed. (Philadelphia: Temple University Press, 2000) 225 at 231-32; Lisa Sarmas, "Storytelling and the Law: A Case Study of Louth v Diprose" (1994) 19 Melbourne U.L. Rev. 701 at 703, 724-26. 
reports and other written texts as "complete” accounts of the events at issue. ${ }^{49}$ Indeed, Karl Llewellyn cautions against reliance on case reports as complete accounts of cases and instead advocates looking at the "brute events outside" the case for a more complete picture. ${ }^{50}$

This is not to suggest that written texts and film serve different purposes. In fact, written text or judgments and film have much in common. As mediums of communication and modes of pedagogy, legal decisions/text and film share epistemological authority: they are both engaged in constructions of "truth" and "social reality." Meanwhile, this "truth," whether in film or judgment, is influenced by the purpose and context of the film or judgment. For instance, Muir was not about ascertaining whether the plaintiff was illegally sterilized. It was about whether the government was liable for false imprisonment and the determination of damages for her victimization. Hence the story told in the Muir decision focuses on her wrongful confinement in the PTS and calculating the amount of compensation to which she was entitled. ${ }^{51}$

Filmmakers and judges are limited by the evidence they have to work with and must make choices between competing accounts of the "truth." 52 As well, the background and social location of the author or filmmaker in terms of, for example, race, gender, or class may influence their representation of truth or telling of the story, often without explicit acknowledgment of the power relations vis-à-vis the subject and object. ${ }^{53}$ Similarly, the ability to see and hear witnesses helps a decision-maker make a judgment about the events, while film audiences are also able to "bear witness" to events by seeing and hearing them on screen. In fact, the filmic medium appears to give viewers more control over the meaning to be derived from the visual images since they experience subjects telling their stories or the unfolding of the pro-filmic event. ${ }^{54}$ In contrast, with written text the reader often does not have the benefit of seeing the evidence that formed the basis of the author's account.

After seeing and hearing testimonies from the parties, witnesses, and experts when appropriate, judges render accounts of cases that are perceived as authoritative, impartial, and true representations of what transpired between the parties, presumably based on the idea of brute perception. This explains the considerable degree of deference to the trial judge's account of the facts. Appellate courts rarely disturb a trial judge's findings of fact because the latter had the opportunity to see and hear the parties and witnesses, assess their credibility, and evaluate the "truth" of their testimonies. For a discussion of the standard of appellate review, see Housen v. Nikolaisen, 2002 SCC 33, [2002] 2 S.C.R. 235; H.L. v. Canada (A.G.), 2005 SCC 25, [2005] 1 S.C.R. 401 at paras. 9, 110.

50 K.N. Llewellyn, The Bramble Bush: On Our Law and its Study (New York: Oceana Publications, 1951) at 40 .

51 Similarly, Peggy Cooper Davis speculates that the film Omar \& Pete, DVD (PBS, 2005), a story about the Maryland rehabilitative program, was structured to tell a particular story, to provide support for the program, criticize excessive use of incarceration, and convince judges about the rehabilitative potential of the program notwithstanding high rates of recidivism: Peggy Cooper Davis, "What Does Documentary Filmmaking Have to do with Practicing Law?” (2008) 8:7 University of Maryland Law Journal of Race, Religion, Gender and Class 7 at 8. See also Corey Shdaimah, "The Power of Perspective: Teaching Social Policy with Documentary Film” (2009) 29 Journal of Teaching in Social Work 85 at $90-91$.

$52 \quad$ Charles Musser, "Film Truth, Documentary, and the Law: Justice at the Margins” (1996) 30 U.S.F. L. Rev. 963 at 976-78. See also Silbey, supra note 47 at 141-42.

53 See The Honourable Maryka Omatsu, “The Fiction of Judicial Impartiality” (1997) 9 C.J.W.L. 1.

54 Plantinga, supra note 19 at 111 . Plantinga suggests that it is this "asserted veridical representation," the combination of "saying” and "showing," that characterizes or defines the documentary film genus. In fact, he argues that exaggerating the meanings of particular assertions in documentaries underestimates the power and affect of visual images and sound recordings to create a phenomenological experience between the viewer and the veridical representations that allows the viewer to interpret those representations in their own way (at 115). 
Just as the testimony of witnesses and court judgments are constructed truths, the filmic medium is not necessarily a representation of the world or reality, but rather a reconstruction of events from the perspective of the subjects or actors, the directors, and the producers of the film. Subjects and filmmakers may use the film not to present the complete picture of the situation or historical event, but rather to tell the story from a subjective viewpoint or pursue particular and often personal objectives,${ }^{55}$ including maintaining ideological hegemony and systems of oppression. ${ }^{56}$ This is particularly true of fictional films and docudramas (films based on true stories or actual events), and is also true of documentaries. For instance, as noted earlier, the Muir documentary does not present a "complete" story. Instead, it gives Muir and others victimized by the eugenics movement in Alberta the opportunity to tell their stories as well as to showcase the filmmaker's position on eugenics.

An example of how filmmakers manipulate the content of films, including documentaries, is the "intention-response model." Filmmakers can employ this model to present images and sounds from a particular perspective or vantage point, intending the message of the documentary to be viewed in a certain way and/or engender a particular affective response from the viewer. ${ }^{57}$ This may especially be the case with voice-over or narrative "expository" documentaries; although intended to be historical accounts of real life events, they are often heavily scripted and hence particularly susceptible to being manipulated by filmmakers. For example, there are several places in the Muir documentary where the viewer is presented with still images of operating rooms and facial expressions of people going before the Board or about to be sterilized, which were marked by terror as a way of inducing a visceral response to the story. With the observational form of documentary, the self-reflexive process of filmmaking means that certain issues are not recorded or photographed at the time of the event, and the documentary becomes a re-enactment of an historical event based on the filmmaker's subjective perception of it. Where the documentary subject is a marginalized person, such a telling of another's story runs the risk of appropriating and silencing their voice and replacing it with the filmmaker's often relatively privileged voice. ${ }^{58}$ In addition, the reconstruction creates opportunities for the filmmaker to manipulate not only the indexical trace or sequence of events, but also the audience's response to the historical account, thereby undermining their truth claims. ${ }^{59}$

In summary, notwithstanding their apparent differences in modes of telling stories or constructing events, legal judgments/written texts and films may be characterized as "illusions of reality," a style, or the author/filmmaker's interpretation based on the evidence, because of their tendency to be self-reflexive. ${ }^{60}$ They also complement each other in telling legal stories. Yet, the filmic medium seems to be accorded greater legitimacy based on the privileging effect of seeing events unfold. In contrast, the written text may be perceived as

\footnotetext{
55 See Rennard Strickland, “Generations: Nanook of the Law School Library and the Classroom” (1999) 5 Mich. J. Race \& L. 31 at 33.

Musser, supra note 52 at 964-66.

Plantinga, supra note 19 at 108.

See Sarmas, supra note 48 at 727, who discusses a similar risk when accounts of cases are told by advocates of "outsiders" who are seemingly representing the voices of the marginalized.

See Plantinga, supra note 19 at 109-10.

See Silbey, supra note 47 at 133-35; Musser, supra note 52 at 967-68. For a critique of the characterization of film as creating an illusory effect, see Leslie J. Moran, "On Realism and the Law Film: The Case of Oscar Wilde” in Leslie J. Moran et al., eds., Law's Moving Image (Portland: Cavendish, 2004) 77 at 90-91.
} 
the author's account of the event. In the next section, we consider our classroom experiences with the various Muir texts, and the ways in which the film assists us in teaching both the particular case and torts more generally.

\section{OUR CLASSROOM EXPERIENCE WITH THE LEILANI MUIR DOCUMENTARY}

We teach Muir as part of a section in the introductory torts course that looks at how the trespass torts can be used to protect individual autonomy and dignity, and more particularly to address sexual wrongdoing, systemic discrimination, and harm. After learning about the general principles of the trespass torts, especially the law's requirement that there be consent to any form of bodily interference, we look more particularly at sexual wrongdoing and unlawful sterilization by state officials. We situate the materials and the discussion in the relatively recent resurgence of interest in using the trespass torts to redress historical and systemic personal interference and disadvantagement, ${ }^{61}$ particularly in situations involving private actors, where the Canadian Charter of Rights and Freedoms ${ }^{62}$ or human rights legislation does not apply. We teach the Muir case after students have spent time in all of their classes learning to navigate their way through written cases, albeit edited ones. ${ }^{63}$ This means that they have the analytical context for understanding the written and visual texts. They are also able to reflect on the ways in which the case illustrates the broader rights-based approach to human dignity and self-determination that is protected by the trespass torts.

We frame the cases and materials as examples of how activist lawyers and litigants have used the trespass torts in new ways to further develop the rights-based nature of the trespass torts and provide justice and compensation for victims of rights violations and systemic harms. Teaching the material in this way also allows us to discuss the ways in which tort law, and the law more generally, responds to novel situations and changing societal norms, and to reflect on the advantages and disadvantages of pursuing justice through private litigation. ${ }^{64}$ We look at a number of groundbreaking cases in this area where survivors sought redress,

See generally John McLaren, "The Intentional Torts to the Person Revived? Protecting Autonomy, Dignity and Emotional Welfare in a Pluralistic Society” (2002) 17 Sup. Ct. L. Rev. (2d) 66.

62 Part I of the Constitution Act, 1982, being Schedule B to the Canada Act 1982 (U.K.), 1982, c. 11.

63 We have a number of reasons for giving students edited cases. These include giving students a manageable workload, and using the editing process to highlight the points about "the law" that we are teaching. In addition, in preparing our torts materials we often edit out difficult or disturbing facts and statements to both address the somewhat voyeuristic nature of reading about people's lives and pain and to avoid further exploiting them. We are also mindful that our students are differently situated in terms of their lived experiences, and we do not want to revictimize survivors in our classrooms. We acknowledge our agency through the editing process by which we influence the ways in which students experience the case just as other legal actors such as lawyers influence stories told in cases through the pleadings, the evidence they choose to present, and their manner of presentation: see Miller, supra note 2 at 297-300; Samuels, supra note 3.

$64 \quad$ See Robyn Campbell, Kelly-Ann Fenney \& John McLaren, “Civil Actions for Sexual Assault” (Report prepared with the support of the Dean's Women’s Advisory Committee Gender and Curriculum Project, Faculty of Law, University of Victoria) [unpublished, copy on file with authors]. 
including Norberg v. Wynrib, ${ }^{65}$ M.(K.) v. M.(H.) ${ }^{66}$ and Blackwater v. Plint. ${ }^{67}$ It is within this context that we study Muir and E.(D.) (Guardian ad litem of) v. British Columbia, ${ }^{68}$ another case out of western Canada in which claimants brought actions against the state for wrongful sterilization. The two cases provide an interesting contrast because, unlike Alberta in the Muir case, the Government of British Columbia invoked the limitations defence to defeat the plaintiffs' claim in D.E. ${ }^{69}$

We assign the film along with excerpts from both the written decision and Robertson's expert witness report as the texts to "read" before class. We have chosen not to show the film in class because the subject matter is difficult to deal with and generates varying levels of emotion. Although we warn students about the difficult nature of the subject matter of the film, our experience is that this does not adequately prepare them for what they see in the film. Students can view the film in the library's viewing room or at home, and can watch it alone or in the company of people who can support them. While this might seem like an effort to keep emotion out of our classrooms, it is our sense that this private or semi-private viewing is more comfortable for students. It also provides them with the time to reflect on their emotional and intellectual responses to the film before they are expected to speak publicly about the issues in the classroom. ${ }^{70}$ Viewing the film outside of class has the added benefit of creating more time for in class discussion. ${ }^{71}$

Our experience with teaching the Muir case in this way is that the affective response of the documentary captivates students' attention, often more so than merely reading the written decision. Students are also interested in seeing the footage of the case in action, before the decision is handed down. The texts we use provide rich material for discussion and reflection on a wide range of issues. For example, the Muir case makes visible the complicity of law in creating and maintaining systems of oppression against marginalized people. Many

[1992] 2 S.C.R. 226. Laura Norberg successfully sued the defendant, a doctor, in battery for exploiting her vulnerability (she was addicted to painkillers) rather than helping her to overcome her addiction by suggesting a sex-for-drugs arrangement with her. The Court rejected the defence of consent because the defendant abused his position of trust and authority, which undermined the reality of Norberg's consent. [1992] 3 S.C.R. 6 [M.(K.)]. In M.(K.), the appellant successfully sued her father for incest and breach of fiduciary duty notwithstanding that she initiated her claim about ten years after she became an adult. The Court found that although she was aware of the fact of abuse, she did not discover the connection between this wrong and the psychological difficulties she was experiencing until she began therapy. Since she initiated her claim within two years of discovering this connection, the defendant's limitation defence failed.

672005 SCC 58, [2005] 3 S.C.R. 3 [Plint]. Plint was one of the first cases in which former students of Indian Residential schools successfully sued school employees in battery for sexual abuse (the claims for non-sexual abuse were dismissed because they were statute-barred). The federal government and religious organizations were held to be vicariously liable for the torts committed by their employees. See also K.L.B. v. British Columbia, 2003 SCC 51, [2003] 2 S.C.R. 403; A. (T.W.N.) v. Clarke, 2003 BCCA 670, 235 D.L.R. (4th) 13.

682005 BCCA 134, 252 D.L.R. (4th) 689 [D.E.]

69 On appeal, some of the plaintiffs were successful because the Court of Appeal found that their sterilization constituted sexual assault for which there is no limitation period in British Columbia: Limitation Act, R.S.B.C. 1996, c. 266, ss. 3(4)(k)-(l). The province chose not to appeal the Court of Appeal's decision.

70 In some years, students have been asked to write short one or two page reflection pieces on any aspect of the torts materials or class discussions. Many have chosen to reflect on the film and the case in one of these pieces.

71 We used to show the film in class, but realized that there was often silence after the end of the viewing. It was difficult to generate a discussion. It seemed to us that students found it difficult to talk about the film immediately after the viewing. As well, there did not appear to be much opportunity for reflections and thoughtful discussions when students had to talk about the film immediately after seeing it. It took much more effort on our part to get the discussion going. 
students are shocked to discover this part of Canadian history, as well as the eugenics philosophy underlying the legislative scheme and its relatively recent repeal. ${ }^{72}$

The case also shows the potential of the trespass torts to remedy violations of bodily integrity, security, and systemic discrimination. In discussing this aspect of Muir, we highlight how the causes of action students are studying can be relevant in the lives of real individuals, and can be used to empower marginalized persons victimized because of their vulnerability. We also want to encourage students to think about how they can use that knowledge in their own work to make visible the discriminatory treatment of marginalized persons and to achieve social change through private law. This seems to be a particularly important goal because of the tendency of students to focus on public law as the route to social change.

At the same time, Muir also opens up space for discussion of some limits of law as a mechanism for remedying wrongs. Victimization of marginalized people in the form of interference with their bodily autonomy and reproductive rights does not necessarily entitle victims to a remedy. As both the case report and documentary indicate, Muir was one of about 3,000 people sterilized in Alberta under the Sexual Sterilization Act. A number of people were also sterilized in British Columbia under that province's sterilization legislation without their knowledge or consent. Muir's claim was "successful” not because she was sterilized, but because her sterilization was not in accordance with the statutory regime. As well, Muir's case could have been time-barred had the Government of Alberta not agreed to waive the limitations defence. ${ }^{73}$ Persons sterilized without their consent, but in accordance with the law at the time, were not entitled to a legal remedy, although some may have received compensation under a settlement process established by the Alberta government subsequent to the Muir case. ${ }^{74}$ Thus, in D.E., the Court dismissed the appeals of those whose sterilizations were not perceived to have constituted misfeasance in public office because the superintendents who recommended their sterilizations did not knowingly exceed their discretion under the legislation. The underlying harm inherent in the assault on the bodies of marginalized people and the perception that they are inferior and not worthy of reproduction are not questioned. The importance of bodily autonomy and integrity and the need for consent for interference with one's body are not perceived to be applicable when it comes to the bodies of marginalized people, notwithstanding the law's willingness to provide a remedy for non-consensual invasions of another's bodily autonomy, even for

72 Students are often surprised to see that early Canadian feminists such as Emily Murphy supported the eugenics philosophy and the Sexual Sterilization Act. See reference to Emily Murphy, supra note 36. Not asserting the limitation defence was perceived as an act of good faith and tantamount to an apology. The Court relied in part on this "apology” to justify its decision not to award Muir punitive damages: Muir, supra note 7 at paras. 151-53.

$74 \quad$ Subsequent to the Muir decision, the Government of Alberta set up an out-of-court settlement process as an option for survivors who did not wish to pursue a judicial claim: see Grekul, Krahn \& Odynak, supra note 36 at 364; Holden, supra note 31. It is unclear from the public record whether those entitled to compensation under the settlement process established by the Government of Alberta after Muir's case were all "wrongfully" sterilized. The sterilization of persons who were still institutionalized may not have been in accordance with the Sexual Sterilization Act because, as already noted, sterilization was to be considered only when the person was about to be discharged. The picture is less clear in relation to those who were independent at the time of the settlement. Persons not "wrongfully" sterilized would not have been able to sustain a tort action for compensation because there was no "violation" of their "rights." 
beneficial purposes. ${ }^{75}$ As Kristen Savell notes, the lack of respect for the bodily integrity of "others" by way of forced "sterilization poses a challenge to liberal understandings of the role of law as a mediator between the individual and [society]."

\section{CONCLUSION}

Our use of the Muir documentary in teaching the trespass torts stems from the power of the images and words of the survivors. As Jessica Silbey notes, "film is the most effective teaching tool.... Its effectiveness comes from its unique persuasiveness. Film, especially documentary film, appears to show its audience how a moment in history actually unfolded." ${ }^{\text {77 }}$ Seeing Muir's determination to seek justice, and hearing her talk about how she ended up at the PTS based on her characterization as a "moron" and about her irreversible sterilization in furtherance of the eugenic social engineering project to create the "perfect race," offers a rare view into the broader context of the case. When Muir and other survivors speak directly to viewers about their experiences and feelings about them, the documentary provides an opportunity for victims to be seen as full human beings, and engenders more empathy for and understanding of the people involved. This may be contrasted with the dispassionate experience that often flows from reading a case report and the abstraction of victims from their context necessary to generate legal principles. Readers often fail to obtain a sense of the plaintiff's personal story of victimization, other than perhaps a few excerpts of their testimony in the judgment. ${ }^{78}$

This suggests that complementing case reports with documentaries about them, or about events related to the case, helps to provide alternative and sometimes counter stories to the official account. Not only do documentaries permit a direct engagement with the subjects, but they also provide a context for appreciating the parties' stories and experiences. However, it is important to recognize the limits of documentaries as incontrovertible truth. The aural and visual experience represents a particular and contingent narrative, provides alternative entry points into the case, and offers an engagement with the lived experience of the subjects, while simultaneously emphasizing the constructed nature of representations of truth and justice. The "direct" engagement with the subjects also produces affective responses not always possible with texts, thereby legitimating the place of emotions in law. As well, seeing and hearing subjects talk about their own cases provides counter-stories to the official account of events represented in the case report. This not only challenges the hegemony of the reported case as the "truth," it also reframes the story that is told from the judge's perspective, and from within a particular narrative structure. 